\title{
U.S. Bank Exposure to Emerging-Market Countries during Recent Financial Crises
}

David E. Palmer, of the Board's Division of Banking Supervision and Regulation, prepared this article. Peggy Wolffrum provided research assistance.

Global financial markets have experienced significant volatility in recent years. In two major cases, actual financial crises arose- the first emanating from Asia in 1997 and the second from Russia in 1998. In both crises, financial markets in almost every country were affected, some suffering considerable declines. Emerging-market countries, in particular, were subject to sharp downward market moves.

U.S. banking supervisors monitored these events carefully to determine the potential effect on U.S. banking organizations. ${ }^{1}$ Supervisors analyze information on the amount and type of claims on foreign counterparties held by U.S. banks to assess the potential risks from lending, trading, and other activities conducted by U.S. banks in foreign markets (see box "Types of Claims on Emerging-Market Counterparties"). ${ }^{2}$

Because emerging-market countries exhibited significant market volatility in the recent crises, supervisors paid additional attention to claims on counterparties in those areas. Furthermore, claims on emerging-market counterparties are concentrated at a small number of U.S. banks, which necessitates particular supervisory scrutiny of the international activities of those institutions.

A major purpose of collecting country exposure data is to identify country risk-the potential for a claim on a foreign counterparty held by a U.S. bank to become impaired or eventually subject to losses. Country risk encompasses counterparty credit risk and transfer risk. Counterparty credit risk relates to the inability of a counterparty to repay and may arise from country-specific factors, such as general eco-

1. Hereafter, U.S. banking organizations, which include U.S. banks and bank holding companies, will be referred to as "U.S. banks."

2. U.S. banks report their claims on foreign counterparties quarterly on the Country Exposure Report of the Federal Financial Institutions Examination Council (FFIEC reporting form 009). These claims are aggregated by country and published by the FFIEC as the Country Exposure Lending Survey (available at www.ffiec.gov/E16/ default.htm). nomic or political disruptions; for example, a sharp recession in a foreign country might cause a foreign counterparty to go bankrupt. Transfer risk arises when exchange-rate difficulties (such as a depreciation or currency controls) impair those claims that are not offset by local liabilities; for example, a foreign counterparty might have difficulty acquiring U.S. dollars to repay an obligation that is not denominated in its home currency. Monitoring claims on emerging-market counterparties allows supervisors to identify any developing concentrations of risk that might warrant supervisory action and, if necessary, to assess the effect that a potential emerging-market crisis might have on U.S. banks. ${ }^{3}$

This article focuses on the claims U.S. banks held on emerging-market counterparties during the twoyear period from June 1997 to June 1999 and discusses the different ways that emerging-market claims can be analyzed. In addition, the article provides a short analysis of the claims held by other developed-country banks on emerging-market countries to show the relative size of U.S. bank claims. Finally, the data from the 1997-99 period are discussed in the broader historical context of U.S. banks' country exposure dating back to 1982 .

\section{U.S. BANK CLAIMS ON FOREIGN COUNTERPARTIES}

Country exposure data for June 1997 to June 1999 reveal that the aggregate claims of U.S. banks on counterparties from all foreign countries rose 11 percent, reaching $\$ 756$ billion (table 1). ${ }^{4}$ Cross-border claims (including revaluation gains) stood at $\$ 423$ billion in June 1997 and rose to $\$ 461$ billion in June 1999. Local country claims (including revaluation gains) also rose over the period, from $\$ 257$ billion to $\$ 295$ billion. Despite the overall increase in

3. Supervisors from the Federal Reserve, the Office of the Comptroller of the Currency, and the Federal Deposit Insurance Corporation meet regularly within the framework of the Interagency Country Exposure Review Committee (ICERC) to discuss transfer risk issues that affect U.S. banks. Examiners present ICERC's country assessments to U.S. banks to inform them of potentially risky conditions.

4. Data on the claims of individual banks are not publicly available. 
total claims held by U.S. banks over this period, a slight drop-off occurred in the first two quarters of 1999.
Total claims on counterparties in developed countries and banking centers rose in the aggregate, from $\$ 485$ billion to $\$ 572$ billion (an increase of 18 per-

\section{Types of Claims on Emerging-Market Counterparties}

Data reported on the Country Exposure Lending Survey can be disaggregated by type of claim to provide a picture of the various types of exposure.

\section{Cross-Border versus Local Claims}

Cross-border claims are those booked outside the foreign counterparty's home country, usually at a U.S. bank's head office in the United States. A claim on a Korean bank booked at the U.S. head office or at the Singapore office of a U.S. bank would in both cases be considered a crossborder claim. This type of claim is usually denominated in U.S. dollars.

Local claims on foreign counterparties are those booked in the local offices of the reporting bank, that is, offices located in the country of the counterparty. A claim on a Korean bank booked at the Seoul office of a U.S. bank is considered a local claim.

\section{Revaluation Gains on Foreign Exchange and Derivatives Contracts}

On the Country Exposure Report, off-balance-sheet claims arising from foreign exchange and derivatives contracts are recorded as revaluation gains. ${ }^{1}$ U.S. banks continually determine the market value of these off-balance-sheet contracts- "revaluing" them-to see if a positive or negative value results (based on movements in market factors or other variables). If the contract has a positive market value for the U.S. bank, that is considered a revaluation gain, similar to a claim in that the counterparty owes a payment to the U.S. bank. ${ }^{2}$ For example, if a U.S. bank enters into a contract with a Latin American bank whereby the U.S. bank benefits from a rise in the level of the Brazilian stock market, a subsequent rise in the level of the stock market would translate into a revaluation gain. ${ }^{3}$

1. Technically, revaluation gains are carried on the balance sheet, even though they arise from off-balance-sheet contracts. For the purposes of this explanation, revaluation gains will be categorized as off-balance-sheet claims.

2. Generally, if the contract has a negative value, the resulting revaluation loss is similar to a liability in that the U.S. bank owes a payment to the foreign counterparty.

3. In March 1997, the FFIEC amended the Country Exposure Report in two ways. For the first time, the FFIEC required the reporting of revaluation gains on off-balance-sheet contracts (Schedule 2). Also, the definition for local claims was altered so that instead of reporting local claims denominated in local currency, banks report local country claims (and no longer local currency claims). This change expanded the definition of local claims to include those cases in which local transactions in foreign countries were conducted in non-local currency. If a foreign country had a significant

\section{Initial Claims versus Claims Adjusted for Guarantees}

Some claims initially booked by U.S. banks may be partially or wholly guaranteed by a counterparty in another foreign country (or in the United States). U.S. banks report these initial claims plus any cases in which guarantees on those claims would shift the ultimate risk from the U.S. bank to another counterparty. For example, a U.S. bank might extend a credit to a construction company domiciled in Thailand, but the claim might actually be guaranteed by a Japanese bank. After adjusting for the guarantee, the U.S. bank would report a claim on the Japanese bank and not on the Thai construction company. Aggregating data on claims by country reveals, on a net basis, the extent to which a country has extended guarantees on the initial claims of U.S. banks. For example, Japanese counterparties might guarantee a certain amount of claims that U.S. banks have on other countries over and above the initial claims that U.S. banks have on Japanese counterparties and, thus, as a group would be net guarantors.

\section{Example of Types of Claims}

The following example shows how different types of claims are classified: Bank A has initiated a $\$ 400$ million loan to a Taiwanese company that is booked in New York-a $\$ 400$ million cross-border claim. But if $\$ 100$ million of that claim is guaranteed by a German bank, the adjusted claim is actually $\$ 300$ million (the $\$ 100$ million guaranteed by the German bank is added to Bank A's claims on German counterparties).

Bank A also has a $\$ 200$ million loan outstanding to another Taiwanese company that is booked in Bank A's Taipei office-a $\$ 200$ million local claim. These two claims combined (cross-border and local), represent the total on-balance-sheet claims of Bank A on Taiwanese counterparties- $\$ 500$ million. Finally, Bank A has also entered into an off-balance-sheet contract, arranged in New York, with a Taiwanese counterparty that has generated cross-border revaluation gains of $\$ 50$ million. Total claims now add up to $\$ 550$ million, which can be viewed as either the sum of cross-border and local claims ( $\$ 350$ million plus $\$ 200$ million) or the sum of on-balance-sheet claims and revaluation gains ( $\$ 500$ million plus $\$ 50$ million).

portion of local transactions conducted in U.S. dollars, classifying claims associated with those transactions as local rather than cross-border was considered preferable because generally such claims were locally funded and hence did not involve transfer risk. For most countries, this definitional change had little effect on the amounts reported. 
1. Claims of U.S. banks on foreign counterparties, 1997:Q2-1999:Q2

Millions of dollars except as noted

\begin{tabular}{|c|c|c|c|c|c|c|c|c|c|c|}
\hline \multirow{2}{*}{ Item } & \multicolumn{3}{|c|}{ 1997, quarter ending } & \multicolumn{4}{|c|}{ 1998, quarter ending } & \multicolumn{2}{|c|}{ 1999, quarter ending } & \multirow{2}{*}{$\begin{array}{c}\text { Percent } \\
\text { change, } \\
\text { June } 1997 \\
\text { to } \\
\text { June } 1999\end{array}$} \\
\hline & June 30 & Sept. 30 & Dec. 31 & Mar. 31 & June 30 & Sept. 30 & Dec. 31 & Mar. 31 & June 30 & \\
\hline All countries & 679,613 & 708,216 & 710,674 & 704,884 & 719,889 & 728,628 & 781,784 & 767,707 & 755,653 & 11.2 \\
\hline Cross-border ${ }^{1}$ & 422,493 & 435,861 & 446,619 & 427,900 & 438,186 & 440,663 & 467,733 & 461,028 & 460,797 & 9.1 \\
\hline $\mathrm{Local}^{2} \ldots \ldots$ & 257,120 & 272,355 & 264,055 & 276,984 & 281,703 & 287,965 & 314,051 & 306,679 & 294,856 & 14.7 \\
\hline \multicolumn{11}{|l|}{ Developed countries and } \\
\hline banking centers ${ }^{3} \ldots$ & 484,503 & 500,508 & 507,950 & 501,105 & 522,162 & 543,236 & 596,662 & 581,699 & 572,427 & 18.1 \\
\hline Cross-border ${ }^{1}$ & 314,819 & 316,780 & 330,785 & 319,972 & 332,947 & 348,202 & 376,186 & 371,175 & 372,743 & $\begin{array}{l}10.1 \\
18.4\end{array}$ \\
\hline Local $^{2} \ldots \ldots \ldots$ & 169,684 & 183,728 & 177,165 & 181,133 & 189,215 & 195,034 & 220,476 & 210,524 & 199,684 & 17.7 \\
\hline Emerging-market countries ${ }^{4}$ & 195,110 & 207,708 & 202,724 & 203,779 & 197,727 & 185,392 & 185,122 & 186,008 & 183,226 & -6.1 \\
\hline Cross-border ${ }^{1} \ldots \ldots \ldots$ & 107,674 & 119,081 & 115,834 & 107,928 & 105,239 & 92,461 & 91,547 & 89,853 & 88,054 & -18.2 \\
\hline Local $^{2} \ldots \ldots$. & 87,436 & 88,627 & 86,890 & 95,851 & 92,488 & 92,931 & 93,575 & 96,155 & 95,172 & 8.8 \\
\hline \multicolumn{11}{|l|}{$\begin{array}{l}\text { Memo: } \\
\text { Emerging-market claims }\end{array}$} \\
\hline As a percentage of all claims & 28.7 & 29.3 & 28.5 & 28.9 & 27.5 & 25.4 & 23.7 & 24.2 & 24.2 & \\
\hline $\begin{array}{l}\text { percentage of all } \\
\text { cross-border claims } \ldots . . .\end{array}$ & 25.5 & 27.2 & 25.9 & 25.2 & 24.0 & 21.0 & 19.6 & 19.5 & 19.1 & \\
\hline $\begin{array}{l}\text { Local claims as a percentage } \\
\text { of all local claims } . . . . .\end{array}$ & 34.0 & 32.5 & 32.9 & 34.6 & 32.8 & 32.3 & 29.8 & 31.4 & 32.3 & \\
\hline
\end{tabular}

1. Cross-border claims are those booked outside the foreign counterparty's home country, usually at a U.S. bank's head office in the United States.

2. Local claims are those booked in the U.S. bank's local offices in the foreign counterparty's country.

4. See table 2 for a list of emerging-market countries by region. Not applicable.

cent). ${ }^{5}$ Cross-border claims rose at about the same pace as local claims and generally represented twothirds of total claims on developed countries and banking centers over the period.

In contrast, combined cross-border and local claims on counterparties in emerging-market countries fell from $\$ 195$ billion to $\$ 183$ billion, a 6 percent drop. ${ }^{6}$ Cross-border claims fell significantly over the period, from $\$ 108$ billion to $\$ 88$ billion, while local claims rose 9 percent, from $\$ 87$ billion to $\$ 95$ billion. By the end of the period, cross-border claims had fallen to less than half of total claims for emerging-market countries. Notably, by June 1999, local claims represented a larger portion of total claims on emergingmarket countries (52 percent) than of total claims on developed countries (35 percent).

Despite volatile conditions in many emerging markets in recent years, U.S. banks continued to maintain one-quarter of their total foreign claims and one-third of local claims on counterparties in these markets. Although there was a significant retreat from some particularly troubled emerging-market countries, claims on counterparties in others actually increased. These increases may have resulted because U.S. banks view local business in many emerging markets as a strategic growth area, largely as a result of recent market liberalization and the increased openness

5. Banking centers are countries where international banks often book assets not associated with economic activity in that country, mostly for tax reasons or to establish a regional headquarters.

6. Table 2 contains the list of emerging-market countries. to U.S. and other developed-country banks in these markets.

\section{Claims on Emerging-Market Counterparties}

From June 1997 to June 1999, claims on counterparties in the countries directly affected by the two major crises registered serious declines (table 2). Total claims on the five troubled countries in AsiaIndonesia, Korea, Malaysia, the Philippines, and Thailand-fell from $\$ 55$ billion in June 1997 to $\$ 37$ billion in June 1999, with claims on Indonesia and Thailand both dropping more than 40 percent. Total claims on counterparties in Eastern Europe fell 42 percent, mainly because of a decline in the value of claims on counterparties in Russia, which plummeted from a peak of \$9 billion in September 1997 to \$940 million in June 1999.

By contrast, total claims on Latin American counterparties rose 13 percent over the period, driven by strong increases in Argentina and Mexico. Interestingly, while Latin American financial markets experienced considerable volatility over the period, U.S. banks did not withdraw from that region. For several decades, U.S. banks have maintained a sizable presence in Latin America, and two years of crisis in other emerging markets appears to have solidified that position. Thus, during the recent crisis period, U.S. banks did not retreat from emerging markets across the board, but only from certain regions; as a 
2. Total claims of U.S. banks on emerging-market counterparties, by country, 1997:Q2-1999:Q2 Millions of dollars except as noted

\begin{tabular}{|c|c|c|c|c|c|c|c|c|c|c|}
\hline \multirow{2}{*}{ Region and country } & \multicolumn{3}{|c|}{ 1997, quarter ending } & \multicolumn{4}{|c|}{ 1998, quarter ending } & \multicolumn{2}{|c|}{ 1999, quarter ending } & \multirow{2}{*}{$\begin{array}{c}\text { Percent } \\
\text { change, } \\
\text { June } 1997 \\
\text { to } \\
\text { June } 1999\end{array}$} \\
\hline & June 30 & Sept. 30 & Dec. 31 & Mar. 31 & June 30 & Sept. 30 & Dec. 31 & Mar. 31 & June 30 & \\
\hline Africa & 3,403 & 3,545 & 3,119 & 3,048 & 3,621 & 3,609 & 3,267 & $\mathbf{3 , 2 3 0}$ & 3,216 & -5.5 \\
\hline Algeria & 300 & 332 & 146 & 130 & 270 & 270 & 307 & 119 & 137 & -54.3 \\
\hline Cameroon & 0 & 0 & 0 & 0 & 0 & 4 & 7 & 8 & 9 & \\
\hline Egypt .... & 731 & 730 & 666 & 658 & 1,010 & 959 & 937 & 1,108 & 1,184 & 62.0 \\
\hline Ethiopia & 1 & 0 & 1 & 0 & 0 & 1 & 2 & 1 & 2 & 100.0 \\
\hline Gabon .. & 44 & 42 & 52 & 46 & 47 & 58 & 61 & 50 & 47 & 6.8 \\
\hline Ghana & 147 & 173 & 228 & 205 & 204 & 48 & 56 & 76 & 82 & -44.2 \\
\hline Ivory Coast & 247 & 227 & 274 & 303 & 268 & 323 & 236 & 185 & 194 & -21.5 \\
\hline Kenya ..... & 278 & 192 & 168 & 172 & 189 & 195 & 197 & 203 & 144 & -48.2 \\
\hline Malawi & 1 & 1 & 1 & 1 & 1 & 6 & 3 & 2 & 1 & .0 \\
\hline Morocco & 564 & 711 & 469 & 484 & 511 & 482 & 452 & 418 & 442 & -21.6 \\
\hline Nigeria. & 375 & 380 & 303 & 406 & 453 & 401 & 398 & 511 & 412 & 9.9 \\
\hline Senegal & 116 & 130 & 115 & 100 & 97 & 97 & 89 & 77 & 100 & -13.8 \\
\hline Sudan. & 47 & 43 & 35 & 38 & 24 & 4 & 8 & 6 & 6 & -87.2 \\
\hline Tunisia & 344 & 344 & 329 & 300 & 328 & 515 & 307 & 261 & 301 & -12.5 \\
\hline Zaire. & 6 & 4 & 6 & 5 & 11 & 32 & 12 & 9 & 8 & 33.3 \\
\hline Zambia & 49 & 30 & 37 & 37 & 19 & 29 & 24 & 33 & 42 & -14.3 \\
\hline Zimbabwe & 50 & 33 & 54 & 45 & 37 & 32 & 28 & 6 & 7 & -86.0 \\
\hline Other Africa & 103 & 173 & 235 & 118 & 152 & 153 & 143 & 157 & 98 & -4.9 \\
\hline Asia-Pacific & 86,691 & 85,623 & 87,032 & 78,304 & 73,044 & 70,042 & 69,004 & 68,713 & 68,729 & -20.7 \\
\hline China ...... & 3,437 & 3,565 & 3,488 & 2,978 & 2,967 & 2,644 & 2,340 & 2,453 & 3,340 & -2.8 \\
\hline India & 5,136 & 5,036 & 5,069 & 5,221 & 5,196 & 5,518 & 5,427 & 5,655 & 5,790 & 12.7 \\
\hline Indonesia & 7,015 & 8,711 & 9,024 & 6,673 & 5,040 & 4,370 & 4,222 & 4,120 & 4,065 & -42.1 \\
\hline Iran ..... & 1 & 29 & 0 & 0 & 1 & 3 & 0 & 0 & 0 & . . . \\
\hline Iraq & 48 & 48 & 48 & 45 & 48 & 48 & 48 & 48 & 49 & 2.1 \\
\hline Israel & 1,359 & 1,292 & 1,157 & 1,295 & 1,338 & 1,313 & 1,417 & 1,960 & 1,846 & 35.8 \\
\hline Jordan & 166 & 193 & 168 & 160 & 157 & 167 & 205 & 190 & 203 & 22.3 \\
\hline Korea . & 23,397 & 22,939 & 25,270 & 22,192 & 20,202 & 18,211 & 17,335 & 18,006 & 17,027 & -27.2 \\
\hline Kuwait & 474 & 490 & 737 & 631 & 675 & 662 & 533 & 570 & 541 & 14.1 \\
\hline Macao & 83 & 113 & 108 & 107 & 103 & 99 & 94 & 89 & 94 & 13.3 \\
\hline Malaysia & 7,536 & 6,952 & 6,700 & 5,954 & 5,290 & 5,373 & 5,919 & 6,457 & 6,456 & -14.3 \\
\hline Oman ... & 145 & 297 & 245 & 238 & 285 & 269 & 291 & 341 & 299 & 106.2 \\
\hline Pakistan & 2,062 & 2,075 & 2,123 & 2,037 & 1,808 & 1,768 & 1,504 & 1,528 & 1,366 & -33.8 \\
\hline Philippines & 6,023 & 5,247 & 4,899 & 4,794 & 4,659 & 4,557 & 4,822 & 4,151 & 4,518 & -25.0 \\
\hline Qatar ..... & 121 & 139 & 169 & 147 & 168 & 185 & 148 & 157 & 222 & 83.5 \\
\hline Saudi Arabia & 1,526 & 1,588 & 1,821 & 1,873 & 2,075 & 3,150 & 2,984 & 2,831 & 2,567 & 68.2 \\
\hline Sri Lanka ... & 53 & 80 & 50 & 71 & 75 & 79 & 58 & 59 & 68 & 28.3 \\
\hline Syria .... & 5 & 5 & 5 & 5 & 0 & 2 & 0 & 0 & 1 & -80.0 \\
\hline Taiwan & 13,307 & 12,596 & 12,821 & 12,413 & 12,667 & $12,17 \overline{5}$ & 12,883 & 12,085 & 12,561 & -5.6 \\
\hline Thailand & 10,845 & 10,357 & 9,350 & 8,072 & 6,874 & 6,616 & 5,567 & 5,123 & 4,770 & -56.0 \\
\hline United Arab Emirates & 1,265 & 1,139 & 1,014 & 1,115 & 975 & 1,079 & 1,456 & 1,287 & 1,271 & .5 \\
\hline Other Asia-Pacific ..... & 2,687 & 2,732 & 2,766 & 2,283 & 2,441 & 1,754 & 1,751 & 1,603 & 1,675 & -37.7 \\
\hline Eastern Europe & 12,589 & 15,983 & 11,880 & 14,152 & 14,299 & 9,136 & 8,517 & 7,536 & 7,321 & -41.8 \\
\hline Bulgaria ........ & 326 & 391 & 203 & 228 & 123 & 112 & 135 & 117 & 164 & -49.7 \\
\hline Czech Republic & 1,399 & 1,575 & 1,330 & 1,535 & 1,648 & 1,890 & 1,719 & 1,573 & 1,383 & -1.1 \\
\hline Hungary ....... & 932 & 1,158 & 946 & 1,464 & 1,568 & 1,444 & 1,373 & 1,399 & 1,368 & 46.8 \\
\hline Poland . & 2,007 & 2,017 & 1,925 & 2,403 & 3,260 & 2,720 & 3,064 & 2,465 & 2,475 & 23.3 \\
\hline Romania & 256 & 294 & 178 & 222 & 222 & 225 & 221 & 168 & 131 & -48.8 \\
\hline Russia ......... & 6,773 & 9,307 & 6,156 & 7,266 & 6,621 & 1,822 & 1,047 & 881 & 940 & -86.1 \\
\hline Slovakia .... & 343 & 418 & 435 & 432 & 506 & 521 & 488 & 465 & 481 & 40.2 \\
\hline Other Eastern Europe ... & 553 & 823 & 707 & 602 & 351 & 402 & 470 & 468 & 379 & -31.5 \\
\hline \multicolumn{11}{|l|}{ Latin America and } \\
\hline Caribbean .... & $\mathbf{9 2 , 4 2 7}$ & 102,557 & 100,693 & 108,275 & 106,763 & 102,605 & 104,334 & 106,529 & 103,960 & 12.5 \\
\hline Argentina .... & 17,018 & 20,422 & 20,033 & 22,571 & 22,869 & 22,405 & 23,620 & 24,792 & 23,975 & 40.9 \\
\hline Bolivia ... & 202 & 184 & 262 & 276 & 356 & 562 & 569 & 559 & 574 & 184.2 \\
\hline Brazil . & 30,330 & 32,335 & 33,399 & 37,252 & 35,652 & 29,940 & 27,551 & 27,770 & 28,815 & -5.0 \\
\hline Chile & 10,566 & 11,178 & 11,705 & 11,692 & 11,731 & 11,115 & 10,889 & 10,771 & 8,614 & -18.5 \\
\hline Colombia & 4,813 & 4,909 & 5,024 & 4,389 & 5,198 & 4,832 & 5,078 & 4,957 & 4,651 & -3.4 \\
\hline Costa Rica & 120 & 133 & 140 & 165 & 176 & 174 & 238 & 239 & 274 & 128.3 \\
\hline Dominican Republic & 401 & 451 & 484 & 479 & 467 & 559 & 549 & 469 & 531 & 32.4 \\
\hline Ecuador .......... & 1,068 & 1,321 & 905 & 949 & 912 & 867 & 956 & 732 & 656 & -38.6 \\
\hline El Salvador .... & 461 & 401 & 457 & 442 & 443 & 438 & 376 & 395 & 435 & -5.6 \\
\hline Guatemala ... & 326 & 437 & 370 & 387 & 446 & 723 & 634 & 509 & 483 & 48.2 \\
\hline Honduras .... & 118 & 136 & 152 & 169 & 194 & 181 & 199 & 180 & 169 & 43.2 \\
\hline Jamaica ... & 222 & 249 & 218 & 236 & 253 & 246 & 256 & 227 & 249 & 12.2 \\
\hline Mexico & 19,486 & 21,020 & 18,801 & 20,088 & 19,069 & 22,108 & 24,145 & 26,079 & 25,227 & 29.5 \\
\hline Nicaragua . & 17 & 21 & 32 & 15 & 28 & 35 & 32 & 22 & 15 & -11.8 \\
\hline Paraguay . . & 353 & 421 & 461 & 472 & 438 & 445 & 484 & 552 & 456 & 29.2 \\
\hline Peru ..... & 1,289 & 1.611 & 1,893 & 2,053 & 2,146 & 1,912 & 2,121 & 2,126 & 2,319 & 79.9 \\
\hline Trinidad and Tobago & 169 & 286 & 397 & 379 & 376 & 401 & 404 & 275 & 329 & 94.7 \\
\hline Uruguay ........... & 1,530 & 1,604 & 1,667 & 1,698 & 1,711 & 1,936 & 2,128 & 1,959 & 1,953 & 27.6 \\
\hline Venezuela $\ldots \ldots \ldots \ldots$ & 3,374 & 3,438 & 3,723 & 3,817 & 3,623 & 3,141 & 3,344 & 3,188 & 3,325 & -1.5 \\
\hline $\begin{array}{l}\text { Other Latin America and } \\
\text { Caribbean ......... }\end{array}$ & 564 & 2,000 & 570 & 746 & 675 & 585 & 761 & 728 & 910 & 61.3 \\
\hline All & 195,110 & 207,708 & 202,724 & 203,779 & 197,727 & 185,392 & 185,122 & 186,008 & 183,226 & -6.1 \\
\hline
\end{tabular}


3. Distribution of total claims of U.S. banks on emerging-market counterparties, by region, 1997:Q2-1999:Q2 Percent

\begin{tabular}{|c|c|c|c|c|c|c|c|c|c|}
\hline \multirow{2}{*}{ Region } & \multicolumn{3}{|c|}{ 1997, quarter ending } & \multicolumn{4}{|c|}{ 1998, quarter ending } & \multicolumn{2}{|c|}{ 1999, quarter ending } \\
\hline & June 30 & Sept. 30 & Dec. 31 & Mar. 31 & June 30 & Sept. 30 & Dec. 31 & Mar. 31 & June 30 \\
\hline Total & 100 & 100 & 100 & 100 & 100 & 100 & 100 & 100 & 100 \\
\hline Africa & 1.7 & 1.7 & 1.5 & 1.5 & 1.8 & 1.9 & 1.8 & 1.7 & 1.8 \\
\hline $\begin{array}{l}\text { Asia-Pacific } \ldots \ldots \\
\quad \text { Troubled } \text { Asia }^{1}\end{array}$ & $\begin{array}{l}44.4 \\
28.1\end{array}$ & $\begin{array}{l}41.2 \\
26.1\end{array}$ & $\begin{array}{l}42.9 \\
27.3\end{array}$ & $\begin{array}{l}38.4 \\
23.4\end{array}$ & $\begin{array}{l}36.9 \\
21.3\end{array}$ & $\begin{array}{l}37.8 \\
21.1\end{array}$ & $\begin{array}{l}37.3 \\
20.5\end{array}$ & $\begin{array}{l}36.9 \\
20.4\end{array}$ & $\begin{array}{l}37.5 \\
20.1\end{array}$ \\
\hline $\begin{array}{r}\text { Eastern Europe } \\
\text { Russia ....... }\end{array}$ & $\begin{array}{l}6.5 \\
3.5\end{array}$ & $\begin{array}{l}7.7 \\
4.5\end{array}$ & $\begin{array}{l}5.9 \\
3.0\end{array}$ & $\begin{array}{l}6.9 \\
3.6\end{array}$ & $\begin{array}{l}7.2 \\
3.3\end{array}$ & $\begin{array}{l}4.9 \\
1.0\end{array}$ & $\begin{array}{r}4.6 \\
.6\end{array}$ & $\begin{array}{r}4.1 \\
.5\end{array}$ & $\begin{array}{r}4.0 \\
.5\end{array}$ \\
\hline Latin America and Caribbean & 47.4 & 49.4 & 49.7 & 53.1 & 54.0 & 55.3 & 56.4 & 57.3 & 56.7 \\
\hline
\end{tabular}

Note. See notes to table 1 . In this and the following tables, percentage distributions may not sum to 100 because of rounding.

result, the relative share of claims among regions shifted (table 3).

\section{Cross-Border versus Local Claims}

Over the June 1997-June 1999 period, cross-border claims on emerging-market counterparties fell markedly, while local claims rose somewhat. Cross-border claims fell 18 percent as a result of declines in Asia (36 percent) and Eastern Europe (60 percent). Unlike Asia and Eastern Europe, cross-border claims on Latin American counterparties rose slightly (table 4).

In the aggregate, local claims in emerging-market countries grew 9 percent over the period (table 5). Although local claims in Asia declined 6 percent overall, only in Thailand did they fall consistently over the period; in Korea, local claims actually rose 19 percent. The overall decrease in Asia was offset by strong increases in Latin America, led by Argentina (72 percent) and Mexico (96 percent).

One explanation for the disparity between movements in cross-border and local claims is that U.S. banks have made significant efforts to establish a
1. The troubled Asian countries are Indonesia, Korea, Malaysia, the Philippines, and Thailand.

local presence in many emerging-market countries, in part because of expections of higher profit margins from banks' local business. ${ }^{7}$ But establishing a profitable local business usually requires a long-term commitment to local markets. As a result, banks have an incentive to maintain local market share and stand by local counterparties in downturns. In addition, severe exchange-rate depreciation often accompanies emerging-market crises, as occurred in Asia and Russia, so that dollar-denominated claims (usually in the form of cross-border claims) become more expensive for emerging-market counterparties to repay, given the decline in local currency relative to the U.S. dollar. As a result, U.S. banks may have been forced to write off more of these cross-border claims as losses, may have decided against extending new claims, or may have done both. Thus, supervisors have an interest in monitoring the growth of crossborder versus local claims because in a crisis, these two types of claims might be affected differently.

7. A number of recently liberalized emerging markets are considered less competitive and may offer opportunities for higher profits.

4. Cross-border claims of U.S. banks on emerging-market counterparties, by region, 1997:Q2-1999:Q2 Millions of dollars except as noted

\begin{tabular}{|c|c|c|c|c|c|c|c|c|c|c|}
\hline \multirow{2}{*}{ Region } & \multicolumn{3}{|c|}{ 1997, quarter ending } & \multicolumn{4}{|c|}{ 1998, quarter ending } & \multicolumn{2}{|c|}{ 1999, quarter ending } & \multirow{2}{*}{$\begin{array}{c}\text { Percent } \\
\text { change, } \\
\text { June } 1997 \\
\text { to } \\
\text { June } 1999\end{array}$} \\
\hline & June 30 & Sept. 30 & Dec. 31 & Mar. 31 & June 30 & Sept. 30 & Dec. 31 & Mar. 31 & June 30 & \\
\hline Total & 107,674 & 119,081 & 115,834 & 107,928 & 105,239 & 92,461 & 91,547 & $\mathbf{8 9 , 8 5 3}$ & 88,054 & -18.2 \\
\hline Africa & 1,661 & 1,979 & 1,543 & 1,413 & 1,719 & 1,369 & 1,411 & 1,210 & 1,193 & -28.2 \\
\hline Asia-Pacific & 43,092 & 45,783 & 47,839 & 37,145 & 33,701 & 30,872 & 28,480 & 28,516 & 27,651 & -35.8 \\
\hline Troubled Asia ${ }^{1}$ & 30,018 & 32,803 & 34,658 & 25,555 & 21,877 & 18,736 & 16,757 & 16,367 & 14,758 & -50.8 \\
\hline Eastern Europe & 8,916 & 11,494 & 7,664 & 9,208 & 9,562 & 5,233 & 4,822 & 3,984 & 3,580 & -59.8 \\
\hline Russia ....... & 5,359 & 7,202 & 4,434 & 5,204 & 5,031 & 1,624 & 909 & 737 & 699 & -87.0 \\
\hline Latin America and Caribbean . & 54,005 & 59,825 & 58,788 & 60,162 & 60,257 & 54,987 & 56,834 & 56,143 & 55,630 & 3.0 \\
\hline
\end{tabular}


5. Local claims of U.S. banks on emerging-market counterparties, by region, 1997:Q2-1999:Q2

Millions of dollars except as noted

\begin{tabular}{|c|c|c|c|c|c|c|c|c|c|c|}
\hline \multirow{2}{*}{ Region } & \multicolumn{3}{|c|}{ 1997, quarter ending } & \multicolumn{4}{|c|}{ 1998, quarter ending } & \multicolumn{2}{|c|}{ 1999, quarter ending } & \multirow{2}{*}{$\begin{array}{c}\text { Percent } \\
\text { change, } \\
\text { June } 1997 \\
\text { to } \\
\text { June } 1999\end{array}$} \\
\hline & June 30 & Sept. 30 & Dec. 31 & Mar. 31 & June 30 & Sept. 30 & Dec. 31 & Mar. 31 & June 30 & \\
\hline Total & 87,436 & 88,627 & 86,890 & 95,851 & 92,488 & 92,931 & 93,575 & 96,155 & 95,172 & 8.8 \\
\hline Africa & 1,742 & 1,566 & 1,576 & 1,635 & 1,902 & 2,240 & 1,856 & 2,020 & 2,023 & 16.1 \\
\hline $\begin{array}{l}\text { Asia-Pacific } \ldots \ldots . . . \\
\quad \text { Troubled Asia }\end{array}$ & $\begin{array}{l}43,599 \\
24,798\end{array}$ & $\begin{array}{l}39,840 \\
21,403\end{array}$ & $\begin{array}{l}39,193 \\
20,585\end{array}$ & $\begin{array}{l}41,159 \\
22,130\end{array}$ & $\begin{array}{l}39,343 \\
20,188\end{array}$ & $\begin{array}{l}39,170 \\
20,391\end{array}$ & $\begin{array}{l}40,524 \\
21,108\end{array}$ & $\begin{array}{l}40,197 \\
21,490\end{array}$ & $\begin{array}{l}41,078 \\
22,078\end{array}$ & $\begin{array}{r}-5.8 \\
-11.0\end{array}$ \\
\hline $\begin{array}{l}\text { Eastern Europe } \\
\quad \text { Russia } . . . . . .\end{array}$ & $\begin{array}{l}3,673 \\
1,414\end{array}$ & $\begin{array}{l}4,489 \\
2,105\end{array}$ & $\begin{array}{l}4,216 \\
1,722\end{array}$ & $\begin{array}{l}4,944 \\
2,062\end{array}$ & $\begin{array}{l}4,737 \\
1,590\end{array}$ & $\begin{array}{r}3,903 \\
198\end{array}$ & $\begin{array}{r}3,695 \\
138\end{array}$ & $\begin{array}{r}3,552 \\
144\end{array}$ & $\begin{array}{r}3,741 \\
241\end{array}$ & $\begin{array}{r}1.9 \\
-83.0\end{array}$ \\
\hline Latin America and Caribbean . & 38,422 & 42,732 & 41,905 & 48,113 & 46,506 & 47,618 & 47,500 & 50,386 & 48,330 & 25.8 \\
\hline
\end{tabular}

Revaluation Gains on Foreign Exchange and Derivatives Contracts

Over the past decade, off-balance-sheet transactions, such as derivatives, have played an increasingly larger role in U.S. banks' overall business. The value of derivatives contracts is based on-or "derived" from - the value of other financial or economic variables, such as an exchange rate or a stock market index. When these underlying variables exhibit strong swings, the value of derivatives contracts can be subject to similar or even more volatile swings, depending on the type of contract. As the Asian crisis began to unfold in the second half of 1997, U.S. banks' derivatives contracts with Asian counterparties rose in value, mostly because of sharp declines in underlying variables in Asian economies. ${ }^{8}$

8. For example, before the onset of the crisis a U.S. bank may have entered into a contract with a Thai bank in which the value of the contract depended on the level of the Thai baht relative to the U.S. dollar. The contract may have been structured such that it would have a positive value from the U.S. bank's perspective if the Thai baht fell
1. See note 1 to table 3 .

Revaluation gains on foreign exchange and derivatives contracts during 1997-99 exhibited large swings in value (table 6). For example, aggregate revaluation gains jumped initially from $\$ 5$ billion in June 1997 to $\$ 17$ billion in December 1997, but fell back to initial levels by June 1999. In troubled Asia, these value swings were particularly pronounced: Year-end 1997 levels were nearly five times higher than levels just six months earlier. At the height of the Asian crisis, claims stemming from off-balance-sheet contracts represented 22 percent of total claims on counterparties in troubled Asian countries but by June 1999 had declined to only 4 percent of total claims (chart 1). The drop occurred mostly for three reasons: The underlying market factors recovered to some extent; many of these contracts were short in duration; and U.S. banks wrote off some of the contracts for which payment seemed unlikely. Similar volatility in revaluation gains occurred in Eastern Europe, although

in value; any decline in the baht relative to the dollar would result in a gain for the U.S. bank and a loss for the Thai bank.

6. Revaluation gains of U.S. banks on foreign exchange and derivatives contracts with emerging-market counterparties, by region, 1997:Q2-1999:Q2

Millions of dollars except as noted

\begin{tabular}{|c|c|c|c|c|c|c|c|c|c|c|}
\hline \multirow{2}{*}{ Region } & \multicolumn{3}{|c|}{ 1997, quarter ending } & \multicolumn{4}{|c|}{ 1998, quarter ending } & \multicolumn{2}{|c|}{ 1999, quarter ending } & \multirow{2}{*}{$\begin{array}{c}\text { Percent } \\
\text { change, } \\
\text { June } 1997 \\
\text { to } \\
\text { June } 1999\end{array}$} \\
\hline & June 30 & Sept. 30 & Dec. 31 & Mar. 31 & June 30 & Sept. 30 & Dec. 31 & Mar. 31 & June 30 & \\
\hline Total & 5,377 & 11,712 & 16,681 & 12,190 & 11,406 & 11,312 & 8,993 & 8,560 & 5,480 & 1.9 \\
\hline Africa & 261 & 292 & 226 & 179 & 339 & 195 & 198 & 20 & 49 & -81.2 \\
\hline $\begin{array}{l}\text { Asia-Pacific } \ldots \ldots . . . \\
\quad \text { Troubled Asia }\end{array}$ & $\begin{array}{l}3,519 \\
2,717\end{array}$ & $\begin{array}{l}7,794 \\
6,983\end{array}$ & $\begin{array}{l}13,551 \\
12,306\end{array}$ & $\begin{array}{l}8,996 \\
7,775\end{array}$ & $\begin{array}{l}7,846 \\
6,457\end{array}$ & $\begin{array}{l}6,869 \\
5,237\end{array}$ & $\begin{array}{l}5,816 \\
4,167\end{array}$ & $\begin{array}{l}4,769 \\
3,394\end{array}$ & $\begin{array}{l}2,616 \\
1,593\end{array}$ & $\begin{array}{l}-25.7 \\
-41.4\end{array}$ \\
\hline $\begin{array}{l}\text { Eastern Europe } \\
\quad \text { Russia } . . . \ldots \ldots\end{array}$ & $\begin{array}{r}346 \\
75\end{array}$ & $\begin{array}{r}1,282 \\
898\end{array}$ & $\begin{array}{r}492 \\
71\end{array}$ & $\begin{array}{l}597 \\
144\end{array}$ & $\begin{array}{l}709 \\
203\end{array}$ & $\begin{array}{l}965 \\
157\end{array}$ & $\begin{array}{r}601 \\
74\end{array}$ & $\begin{array}{r}387 \\
14\end{array}$ & $\begin{array}{r}207 \\
0\end{array}$ & $\begin{array}{r}-40.2 \\
-100.0\end{array}$ \\
\hline Latin America and Caribbean . & 1,251 & 2,344 & 2,412 & 2,418 & 2,512 & 3,283 & 2,378 & 3,384 & 2,608 & 108.5 \\
\hline
\end{tabular}

Note. See notes to table 1. See box "Types of Claims on EmergingMarket Counterparties," for a discussion of revaluation gains. 
1. Revaluation gains of U.S. banks on foreign exchange and derivatives contracts with counterparties in troubled Asia as a percentage of total claims on those counterparties, 1997:Q2-1999:Q2

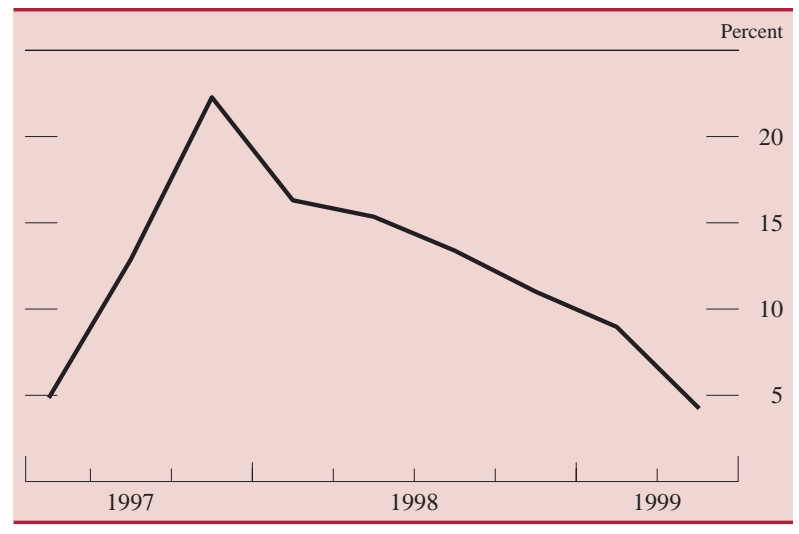

Note. Data are quarterly. Revaluation gains represent the market value of foreign exchange and derivatives contracts. If the contract has a positive market value for the U.S. bank, that amount is considered a revaluation gain, similar to a claim in that the counterparty owes a payment to the U.S. bank.

The troubled Asian countries are Indonesia, Korea, Malaysia, the Philippines, and Thailand.

quarterly swings were not as extreme as those in Asia. ${ }^{9}$ Revaluation gains as a percentage of total claims reached 10 percent for claims in Eastern Europe in September 1998, the peak of the Russian crisis.

Revaluation gains on contracts with counterparties in Latin America doubled over the period - to nearly $\$ 3$ billion. But peak levels were only one-quarter of the peak levels reached in Asia, reflecting in part the relatively less extreme movements in economic variables in Latin America. In addition, U.S. banks were not as likely to engage in less-traditional, off-balancesheet activities (such as derivatives contracts) with Latin American counterparties as they were with counterparties in other regions. ${ }^{10}$

Large market declines during the Asian crisis generated rapid increases in counterparty credit risk for U.S. banks. Essentially, U.S. banks were seeing the market value of their contracts increase, but, in certain cases, so much so that the ability of some Asian counterparties to make payments, given their large losing positions in some contracts, came into question. These contracts are generally marked to market

9. Contracts with Russian counterparties changed drastically in value in August 1998 but by September had largely been charged off.

10. The crisis in Mexico and Latin America in 1994-95 may have led U.S. banks to be more cautious about their derivatives business with Latin American counterparties. In that crisis, a sharp devaluation of the Mexican peso generated large derivatives (and other) losses for Latin American counterparties of U.S. banks. In contrast, before 1997 many U.S. banks, and banks from other countries as well, may have been less concerned about potential losses on contracts with Asian counterparties. on a daily basis, so that losses create additional pressure on foreign counterparties in the midst of a crisis.

Banking supervisors view the increased importance of revaluation gains during the past several years as evidence of change in the nature of country exposure. The increased use of, and broader markedto-market reporting of, derivatives contracts has highlighted the way that market risk and counterparty credit risk interact. In particular, counterparty credit risk can be negatively correlated with market risk, so that a positive market move-from a U.S. bank's perspective-could quickly increase counterparty credit risk. One of the important lessons from the Asian crisis is that a U.S. bank could have completely hedged its market risk and still faced significant counterparty credit risk if a change in market prices affected the ability of the foreign counterparty to pay. In the Russian crisis, some U.S. banks' ability to hedge local currency exposure broke down because Russian banks - suffering heavy losses from the ruble depreciation-were unable or unwilling to make payments owed to U.S. banks.

The fast-moving nature of derivatives markets means that exposure can change more quickly than in the past. Thus banks must rely on even better riskmanagement techniques to ensure that they can manage latent counterparty credit risk that might arise rapidly. In turn, supervisors must caution banks when risk-management techniques do not appear to be fully capturing the risks generated by derivatives contracts with emerging-market counterparties.

The Asian and Russian crises provided lessons for internationally active U.S. banks, and to some extent the banks have been able to apply what they learned. For example, a number of banks are integrating their market risk and counterparty credit risk functions to better manage cases in which one risk arises from the other. In addition, more institutions are stress testing their emerging-market portfolios-in effect "shocking" their current portfolios with a range of possible outcomes. ${ }^{11}$ In the Asian crisis, more thorough stress testing before the events in 1997 might have provided the banks with some warning about the negative effects of severe exchange-rate depreciations.

\section{Distribution by Counterparty Sector}

Starting in June 1997, cross-border claims on counterparties in all emerging-market countries were dis-

11. For example, a U.S. bank might revalue its existing portfolio based on a hypothetical increase in interest rates or a hypothetical decline in the exchange rate. 
tributed evenly among banks, the public sector, and nonbank private counterparties. ${ }^{12}$ By June 1999, the distribution had shifted away from banks and toward the nonbank private sector. Although claims on banks represented 33 percent of all cross-border claims in June 1997, the share had fallen to 25 percent by June 1999. At the same time, the share of claims on the nonbank sector rose from 36 percent to 42 percent. This trend reflects to some extent the difficulties experienced by certain emerging-market banks over the period.

The shift in the distribution of claims among counterparty sectors varied across regions. Much of the shift in aggregate numbers occurred because of changes in cross-border claims on Asian counterparties. In June 1997, banks represented 50 percent of the total for Asia, the nonbank private sector 41 percent, and the public sector 9 percent. By June 1999, the distribution in Asia had shifted toward the public sector and away from banks (table 7). A large number of Asian banks were hindered in their ability to make good on liabilities because of their financial difficulties during the Asian crisis. As a result, U.S. banks wrote off some of their claims on Asian counterparties or at least did not renew them once payment was received. A second factor affecting the aggregate sectoral distribution was the relative increase in claims on Latin American counterparties (as discussed previously). The cross-border claims on Latin American counterparties were distributed more between the public sector and nonbank private sector,

12. Breakdowns by counterparty sector are not reported for local claims; they are available only for cross-border claims. so that this region's increased share of the aggregate contributed to the overall sectoral pattern over the two years. In Russia, the precipitous fall in cross-border claims was driven largely by a 92 percent decline in claims on the public sector, representing a default by the Russian government on its foreign-currency bonds in August and September 1998.

\section{Distribution by Maturity}

On the whole, the maturity distribution of crossborder claims on counterparties in emerging-market countries indicates the continued prevalence of shortterm credits. ${ }^{13}$ For example, the share of cross-border claims with a maturity of one year or less held steady over the period, accounting for two-thirds of crossborder claims. In June 1997, short-term claims on Asian counterparties accounted for about 75 percent of total cross-border claims on counterparties in that region, with the share falling to 65 percent after the crisis. At the beginning of the period, U.S. banks held many short-term claims on Asian banks but, in some instances, did not roll over extensions of credit during and immediately after the crisis.

In Latin America, the maturity distribution shifted slightly toward the short term, but the level of shortterm claims remained below that in emerging Asia. The lower percentage of short-term claims in Latin America may have resulted from a greater share

13. Maturity data are based on initial claims before adjustments for guarantees and do not include revaluation gains.

7. Distribution of cross-border claims of U.S. banks on emerging-market counterparties, by region and counterparty sector, 1997:Q2-1999:Q2

Percent

\begin{tabular}{|c|c|c|c|c|c|c|c|c|c|}
\hline \multirow{2}{*}{ Region and counterparty sector } & \multicolumn{3}{|c|}{ 1997, quarter ending } & \multicolumn{4}{|c|}{ 1998, quarter ending } & \multicolumn{2}{|c|}{ 1999, quarter ending } \\
\hline & June 30 & Sept. 30 & Dec. 31 & Mar. 31 & June 30 & Sept. 30 & Dec. 31 & Mar. 31 & June 30 \\
\hline \multicolumn{10}{|l|}{ Africa } \\
\hline Banks & 20.0 & 13.6 & 16.7 & 19.3 & 18.5 & 20.7 & 25.8 & 25.1 & 26.2 \\
\hline Public sector & 72.7 & 67.6 & 69.1 & 69.2 & 65.7 & 64.0 & 58.7 & 55.3 & 52.3 \\
\hline Nonbank private sector & 7.2 & 18.7 & 14.3 & 11.5 & 15.8 & 15.3 & 15.5 & 19.6 & 21.5 \\
\hline \multicolumn{10}{|l|}{ Asia-Pacific } \\
\hline Banks ..... & 49.9 & 49.9 & 48.5 & 42.5 & 42.8 & 39.1 & 40.4 & 37.6 & 35.2 \\
\hline Public sector & 8.9 & 10.2 & 11.1 & 13.8 & 15.8 & 19.0 & 19.7 & 19.5 & 22.8 \\
\hline Nonbank private sector & 41.2 & 39.9 & 40.4 & 43.6 & 41.4 & 41.9 & 40.0 & 42.9 & 42.0 \\
\hline \multicolumn{10}{|l|}{ Eastern Europe } \\
\hline Banks ......... & 11.9 & 9.4 & 13.3 & 13.8 & 17.1 & 23.1 & 22.4 & 24.9 & 17.6 \\
\hline Public sector ... & 77.6 & 82.1 & 72.8 & 72.6 & 68.4 & 52.5 & 49.9 & 48.8 & 54.8 \\
\hline Nonbank private sector & 10.6 & 8.4 & 14.0 & 13.7 & 14.5 & 24.4 & 27.7 & 26.3 & 27.7 \\
\hline \multicolumn{10}{|l|}{ Latin America and Caribbean } \\
\hline Banks $\ldots \ldots \ldots \ldots \ldots \ldots \ldots$ & 22.2 & 21.4 & 24.7 & 25.1 & 26.3 & 26.3 & 21.2 & 20.4 & 20.3 \\
\hline Public sector & 41.4 & 40.6 & 35.1 & 32.8 & 30.5 & 26.7 & 33.6 & 34.3 & 36.5 \\
\hline Nonbank private sector & 36.5 & 38.0 & 40.2 & 42.2 & 43.2 & 47.0 & 45.3 & 45.3 & 43.2 \\
\hline
\end{tabular}

Note. See notes to table 1 . 
of loans to the public sector, which generally have a longer maturity.

The share of short-term claims in cross-border claims on Eastern Europe fell from a peak of 78 percent in June 1998 to 62 percent in June 1999. By this time, most of the short-term speculative positions in Russian government debt had been closed out. In general, the prevalence of short-term claims indicates that U.S. banks were cautious about extending maturities of claims on emerging-market counterparties in order to have the ability to reduce exposure quickly if a crisis developed.

\section{Initial Claims and Adjustments for Guarantees}

As noted previously, U.S. banks report initial crossborder claims before adjustments for guarantees. Comparing initial claims and adjusted claims shows the extent to which the ultimate risk on those claims is being borne by counterparties outside the country of the initial borrower. ${ }^{14}$ Subtracting claims adjusted for guarantees from initial claims provides a figure for net credit guarantees received (if positive) or net credit guarantees extended by counterparties in those countries (if negative) on initial claims held by U.S. banks. In the aggregate, for claims initiated by U.S. banks, counterparties in emerging-market countries were net receivers of guarantees over the period, meaning that they received more guarantees than they offered. In addition, the percentage of initial claims that received guarantees rose from 10 percent in 1997 to 18 percent in 1999. Not surprisingly, these data indicate that initial claims on emerging-market counterparties held by U.S. banks were sometimes protected by guarantees from counterparties in developed countries or from international development banks. In fact, U.S. banks may have sought greater protection on those initial claims, given the crises in emerging markets.

Interestingly, in 1997 counterparties in emerging Asia were net granters of credit guarantees on the initial claims of U.S. banks because of roughly $\$ 3$ billion in guarantees extended by Korean counterparties, particularly large Korean conglomerates, or chaebols. ${ }^{15}$ That trend in Asia reversed as Korean

14. For example, if a U.S. bank held a claim on a Chinese firm in the amount of $\$ 100$ million, and if $\$ 20$ million of that claim were guaranteed by a French bank, then initial claims on China would be $\$ 100$ million, adjusted claims on China would be $\$ 80$ million, and adjusted claims on France would increase \$20 million.

15. Guarantees extended by Korean counterparties were not restricted to claims on other Korean counterparties; some guarantees applied to initial claims held by U.S banks on other counterparties in emerging Asia. chaebols encountered financial difficulties, so that by 1998 counterparties in Asia, as a group, were net receivers of credit guarantees on initial claims.

Regarding other regions, Latin American counterparties were net receivers of credit guarantees over the entire period, with the amounts ranging between 15 percent and 18 percent of initial claims. The most drastic increase occurred in Eastern Europe, where by June 1999, nearly half of all initial claims were guaranteed. ${ }^{16}$

\section{Claims in Relation to Total Assets and to Tier 1 Capital}

Examined in isolation, the outstanding claims on emerging-market counterparties held by U.S. banks give only a partial view of the relative importance of emerging-market activity for banks. For a more complete picture, supervisors must examine claims as a percentage of assets and as a percentage of capital. Claims as a percentage of capital, in particular, provide supervisors with an initial assessment of U.S. banks' ability to weather the potentially volatile nature of emerging markets.

Over the two-year period, emerging-market claims as a percentage of U.S. bank assets (for those banks reporting country exposure data) fell from 6.7 percent of total assets to 4.5 percent, a result more of the overall increase in total assets than of the decline in claims (table 8). For example, even though total claims on counterparties in Latin America registered double-digit growth, that growth rate was outpaced by that of the reporting banks' total assets, thus driving the percentage of claims-to-assets for that region lower. The decline in this percentage for Asian counterparties, for which claims fell, was even more dramatic.

Total claims as a percentage of tier 1 capital peaked in September 1997 at 105 percent (table 8). ${ }^{17}$ However, by June 1999 that percentage had fallen to 72 percent, a decline stemming mostly from a significant increase in tier 1 capital (chart 2). Total claims on Latin American counterparties as a percentage of tier 1 capital fell slightly over the period, but never

16. U.S. banks are increasingly involved with credit derivatives, which transfer counterparty credit risk to a third party. As the credit derivatives market grows, there may be many more cases in which supervisors will want to examine shifts in counterparty credit risk from the initial obligor to a third party, similar to the way guarantees transfer risk.

17. Tier 1 capital generally consists of common stockholders' equity, noncumulative perpetual preferred stock and any related surplus, and minority interests in equity capital accounts of consolidated subsidiaries 
8. Total claims of U.S. banks on emerging-market counterparties as a percentage of reporting banks' assets and reporting banks' tier 1 capital, 1997:Q2-1999:Q2

\begin{tabular}{|c|c|c|c|c|c|c|c|c|c|}
\hline \multirow{2}{*}{ Region } & \multicolumn{3}{|c|}{ 1997, quarter ending } & \multicolumn{4}{|c|}{ 1998, quarter ending } & \multicolumn{2}{|c|}{ 1999, quarter ending } \\
\hline & June 30 & Sept. 30 & Dec. 31 & Mar. 31 & June 30 & Sept. 30 & Dec. 31 & Mar. 31 & June 30 \\
\hline & \multicolumn{9}{|c|}{ Percentage of reporting banks' total assets } \\
\hline Total emerging-market claims & 6.7 & 6.8 & 6.2 & 6.0 & 5.8 & 5.3 & 4.8 & 4.8 & 4.5 \\
\hline Africa & .1 & .1 & .1 & .1 & .1 & .1 & .1 & .1 & .1 \\
\hline Asia-Pacific & 3.0 & 2.8 & 2.7 & 2.3 & 2.1 & 2.0 & 1.8 & 1.8 & 1.7 \\
\hline Troubled Asia ${ }^{1}$ & 1.9 & 1.8 & 1.7 & 1.4 & 1.2 & 1.1 & 1.0 & 1.0 & .9 \\
\hline Eastern Europe ... & .4 & .5 & .4 & .4 & .4 & .3 & .2 & .2 & .2 \\
\hline Russia ....... & .2 & .3 & .2 & .2 & .2 & .1 & .0 & .0 & .0 \\
\hline \multirow[t]{2}{*}{ Latin America and Caribbean } & 3.2 & 3.3 & 3.1 & 3.2 & 3.1 & 2.9 & 2.7 & 2.7 & 2.6 \\
\hline & \multicolumn{9}{|c|}{ Percentage of reporting banks' tier 1 capital } \\
\hline Total emerging-market claims & 102.1 & 104.6 & 97.0 & 93.9 & 88.5 & 80.3 & 75.7 & 73.2 & 72.3 \\
\hline Africa & 1.8 & 1.8 & 1.5 & 1.4 & 1.6 & 1.6 & 1.3 & 1.3 & 1.3 \\
\hline Asia-Pacific & 45.4 & 43.1 & 41.6 & 36.1 & 32.7 & 30.3 & 28.2 & 27.0 & 27.1 \\
\hline Troubled Asia ${ }^{1}$ & 28.7 & 27.3 & 26.4 & 22.0 & 18.8 & 17.0 & 15.5 & 14.9 & 14.5 \\
\hline Eastern Europe ... & 6.6 & 8.0 & 5.7 & 6.5 & 6.4 & 4.0 & 3.5 & 3.0 & 2.9 \\
\hline Russia ........ & 3.5 & 4.7 & 2.9 & 3.3 & 3.0 & .8 & .4 & .3 & .4 \\
\hline Latin America and Caribbean & 48.4 & 51.6 & 48.2 & 49.9 & 47.8 & 44.5 & 42.7 & 41.9 & 41.0 \\
\hline
\end{tabular}

Note. For a definition of tier 1 capital, see text note 17.

1. See note 1 to table 3 .

below 41 percent. In contrast, total claims on Asian counterparties fell from 45 percent of tier 1 capital to 27 percent. Total claims on Eastern European counterparties peaked at 8 percent of tier 1 capital about one year before the onset of the crisis in Russia. Generally, internationally active U.S. banks reduced their exposure to emerging markets while bolstering their capital.

As discussed earlier, supervisors cannot assess country risk by simply looking at the absolute levels of claims. Claims-to-capital figures serve as a preliminary indicator of how much cushion U.S. banks might have available to absorb potential losses in

2. U.S. banks' emerging-market claims compared with tier 1 capital, 1997:Q2-1999:Q2

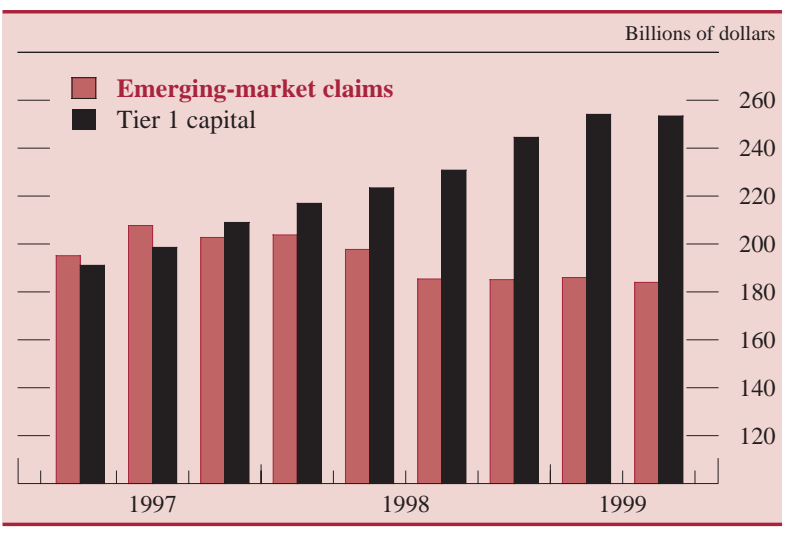

Note. Tier 1 capital consists of common stockholders' equity, noncumulative perpetual preferred stock and any related surplus, and minority interests in equity capital accounts of consolidated subsidiaries. Tier 1 capital data cover only banks that file the Country Exposure Report. their emerging-market portfolios. When viewed at the level of the individual institution, these figures allow supervisors to recognize those institutions with high exposure relative to capital. Banks identified as having elevated claims-to-capital ratios receive greater supervisory scrutiny in the area of country risk. For example, supervisors would focus on a bank with a claims-to-capital ratio of more than 100 percent, even if the amount of claims was small. But claims-to-capital ratios, on their own, might not always reflect the underlying riskiness of the claims or the ability of the banks to manage that risk, so supervisors conduct assessments of the riskmanagement systems of individual banks to achieve a more accurate picture of how country risk is affecting those institutions.

For the most part, U.S. banks did not suffer large losses stemming directly from emerging-market crises in recent years. When banks did suffer losses, they were generally able to offset them with earnings from other business segments. ${ }^{18}$ In fact, the ability of U.S. banks to charge their losses in Asia and Russia against income-rather than drawing down their capital-indicates both their high levels of overall profitability during this period and their low levels of exposure. It is possible, however, that a similar period of international crisis coinciding with a domestic downturn in the United States might have put pressure on U.S. banks' capital positions.

18. See Antulio N. Bomfim and William R. Nelson, "Profits and Balance Sheet Developments at U.S. Commercial Banks in 1998," Federal Reserve Bulletin, vol. 85 (June 1999), pp. 369-95. 


\section{Concentrations among Reporting Banks}

The discussion thus far has centered on U.S. banks in the aggregate. However, because most of the claims on emerging-market counterparties are concentrated at a small number of U.S. banks, a smaller capital base is available to absorb their potential losses. Serious country exposure difficulties at just a few of these banks would have the potential to trigger broader problems within the entire U.S. banking system. In general, supervisors focus on the riskiness of any U.S. bank's foreign claims but are particularly sensitive to the implications of exposure at large banks.

The U.S. banks that report in the "Money Center Banks" category on the Country Exposure Report generally represent those with the largest claims on counterparties in emerging-market countries. ${ }^{19}$ Over the 1997-99 period, money center banks consistently accounted for about 80 percent of total claims on counterparties in emerging markets and more than 40 percent of the total assets of all U.S. banks.

For the money center banks, the share of their emerging-market claims in total assets fell from 13 percent in 1997 to 6 percent in 1999 (table 9). Commensurate with that decline was a decrease in emerging-market claims as a percentage of tier 1 capital, from a peak of 232 percent in 1997 to 113 percent in 1999. Notably, the decrease in this percentage stemmed largely from an 88 percent increase in tier 1 capital.

Analyzing the claims-to-capital ratio for money center banks is especially important, given the concentration of claims on emerging-market counterparties at these banks. Whenever claims-to-capital ratios are identified as particularly high, supervisors may conduct a special analysis of the selected bank's ability to manage country risk in the context of broader risk-management functions.

19. Over time, this group has varied in size from six to nine banks (currently six). See the Country Exposure Lending Survey for details.

\section{EMERGING-MARKET EXPOSURE OF BANKS FROM OTHER DEVELOPED COUNTRIES}

Briefly comparing U.S. banks' exposure to emergingmarket countries over 1997-99 with the exposure of banks from other developed countries provides some overall context for assessing the relative role played by U.S. banks. U.S. banks, along with banks from other developed countries, report their country exposure data to the Bank for International Settlements (BIS), which then compiles data for all of its members and reports the consolidated results. ${ }^{20}$

From June 1997 to June 1999, BIS reporting bank claims on emerging-market counterparties fell in the aggregate from $\$ 829$ billion to $\$ 782$ billion (table 10). Claims on Asian counterparties fell 20 percent, while claims on Latin American and African counterparties rose. By June 1999, claims on Asia still represented the largest share of total emergingmarket claims, but by a smaller margin because of an increase in the share of claims on Latin American counterparties. Compared with U.S. bank data on emerging-market claims, the shifts for Asia and Latin America were relatively similar; however, claims on Eastern European counterparties fell only slightly for all BIS reporting banks, and claims on African counterparties increased almost one-third.

\section{BIS Reporting Bank Claims by Country of Origin}

In June 1997, claims held by U.S. banks accounted for 13 percent of the cross-border claims on emerging-market counterparties held by all BIS

20. These data represent cross-border claims from individual country submissions of claims on non-BIS member countries. The data are consolidated at the BIS to eliminate any double counting and do not include revaluation gains on off-balance-sheet contracts or adjustments for guarantees (for details on BIS data, see www.bis.org). BIS member countries include the Group of Ten, plus Austria, Denmark, Finland, Ireland, Luxembourg, Norway, and Spain. Because the BIS does not collect capital figures for these countries, claims-to-capital ratios cannot be calculated.

9. Total claims of U.S. money center banks on emerging-market counterparties as a percentage of their total assets and tier 1 capital 1997:Q2-1999:Q2

\begin{tabular}{|c|c|c|c|c|c|c|c|c|c|}
\hline \multirow{2}{*}{ Item } & \multicolumn{3}{|c|}{ 1997, quarter ending } & \multicolumn{4}{|c|}{ 1998, quarter ending } & \multicolumn{2}{|c|}{ 1999, quarter ending } \\
\hline & June 30 & Sept. 30 & Dec. 31 & Mar. 31 & June 30 & Sept. 30 & Dec. 31 & Mar. 31 & June 30 \\
\hline $\begin{array}{l}\text { Total emerging-market claims } \\
\text { as a percentage of total assets }\end{array}$ & 13.1 & 13.4 & 12.3 & 11.9 & 11.1 & 8.4 & 7.2 & 6.9 & 6.3 \\
\hline $\begin{array}{l}\text { Total emerging-market claims } \\
\text { as a percentage of tier } 1 \text { capital }\end{array}$ & 225.7 & 232.2 & 205.9 & 204.4 & 190.0 & 144.4 & 121.8 & 113.0 & 112.6 \\
\hline
\end{tabular}

Note. For a definition of tier 1 capital, see text note 17. 
10. Distribution of total claims of BIS reporting banks on emerging-market counterparties, by region, 1997:Q2-1999:Q2

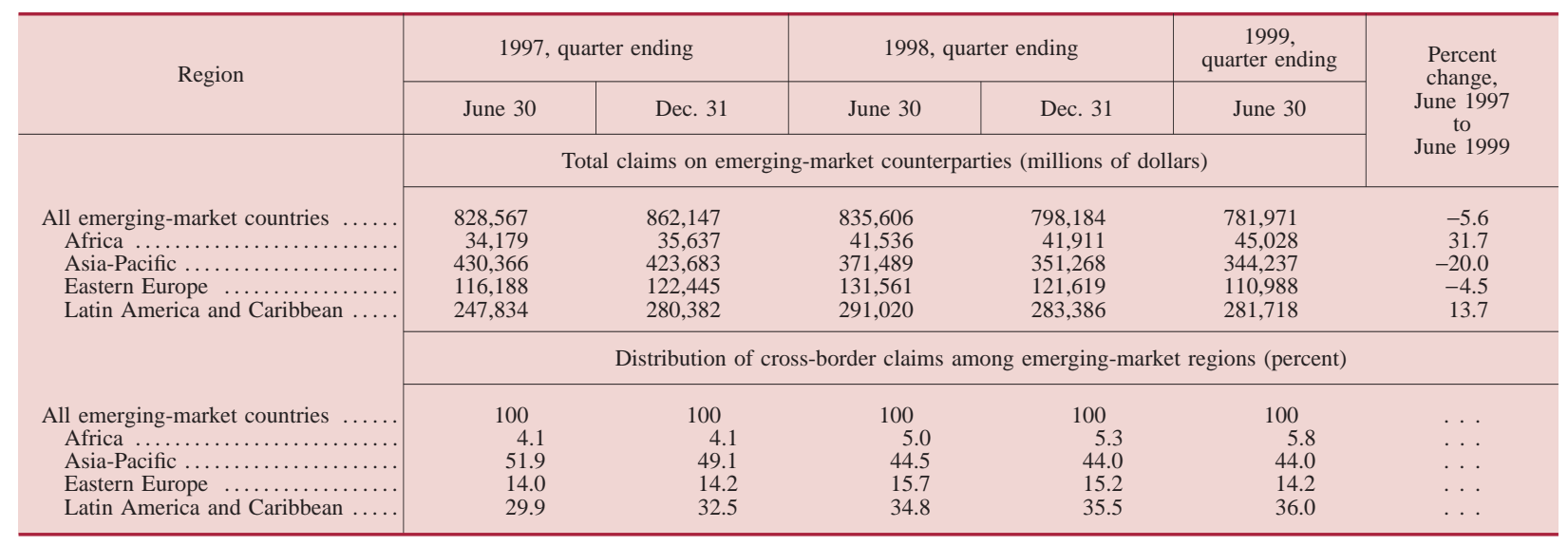

... Not applicable.

reporting banks (table 11). Banks from Japan had the highest share, with Germany a close second. Over the two-year period, the share held by U.S. banks fell slightly. The share of Japan's banks dropped significantly. Japanese banks were facing considerable domestic financial difficulties over this period, which contributed to their retrenchment in emerging markets. Most European reporting banks increased their relative positions.

\section{BIS Reporting Bank Claims by Emerging-Market Region}

A regional breakdown indicates that the relative shares were not uniform by emerging-market regions.
Japanese banks held nearly 30 percent of all claims on Asian counterparties in June 1997, but that share had fallen to 23 percent by June 1999. That decline can be compared with a slight increase in the portion of claims on Asian counterparties held by European banks (nearly 50 percent), while the share held by U.S. banks remained relatively steady (7 percent). In Latin America, U.S. banks held a large share (25 percent), while European banks, as a group, expanded their share of claims to more than 50 percent, led by a rise in the share of Spanish banks. German and other European banks accounted for about two-thirds of all BIS reporting bank claims on Eastern Europe, while the share held by U.S. banks fell by half, to 5 percent.

11. Distribution of cross-border claims of BIS reporting banks on emerging-market counterparties, by lending country, 1997:Q2-1999:Q2

\begin{tabular}{|c|c|c|c|c|c|c|}
\hline \multirow{2}{*}{ Country } & \multicolumn{2}{|c|}{ 1997, quarter ending } & \multicolumn{2}{|c|}{ 1998, quarter ending } & \multirow{2}{*}{$\begin{array}{c}1999, \\
\text { quarter ending } \\
\text { June } 30\end{array}$} & \multirow{3}{*}{$\begin{array}{c}\text { Percent } \\
\text { change, } \\
\text { June } 1997 \\
\text { to } \\
\text { June } 1999\end{array}$} \\
\hline & June 30 & Dec. 31 & June 30 & Dec. 31 & & \\
\hline & \multicolumn{5}{|c|}{ Total cross-border claims on emerging-market counterparties (millions of dollars) } & \\
\hline All reporting banks & 828,567 & 862,147 & 835,606 & 798,184 & 781,971 & -5.6 \\
\hline United States ... & 109,462 & 107,770 & 103,685 & 94,299 & 96,539 & -11.8 \\
\hline Japan ......... & 146,092 & 137,563 & 120,797 & 108,643 & 94,050 & -35.6 \\
\hline Germany .. & 139,626 & 147,911 & 147,484 & 154,347 & 155,079 & 11.1 \\
\hline France ... & 82,824 & 95,683 & 92,090 & 87,750 & 91,054 & 9.9 \\
\hline United Kingdom & 55,260 & 63,607 & 65,728 & 64,504 & 58,141 & 5.2 \\
\hline Other Europe & 130,830 & 149,710 & 160,941 & 159,250 & 149,168 & 14.0 \\
\hline \multirow[t]{2}{*}{ 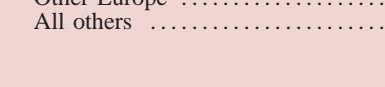 } & 164,473 & 159,904 & 144,881 & 129,392 & 137,940 & -16.1 \\
\hline & \multicolumn{6}{|c|}{ Distribution of cross-border claims amoung reporting banks from BIS-member countries (percent) } \\
\hline All reporting banks & 100 & 100 & 100 & 100 & 100 & $\ldots$ \\
\hline United States & 13.2 & 12.5 & 12.4 & 11.8 & 12.3 & . \\
\hline Japan ........ & 17.6 & 16.0 & 14.5 & 13.6 & 12.0 & $\because$ \\
\hline Germany & 16.9 & 17.2 & 17.6 & 19.3 & 19.8 & $\ldots$ \\
\hline France . . & 10.0 & 11.1 & 11.0 & 11.0 & 11.6 & $\ldots$ \\
\hline United Kingdom & 6.7 & 7.4 & 7.9 & 8.1 & 7.4 & $\because$ \\
\hline Other Europe ... & 15.8 & 17.4 & 19.3 & 20.0 & 19.1 & $\cdots$ \\
\hline All others & 19.9 & 18.5 & 17.3 & 16.2 & 17.6 & . \\
\hline
\end{tabular}

Note. Data in this table do not include adjustments for guarantees; as a result, data for U.S. banks may differ from data reported in earlier tables. 
Overall, the BIS data indicate that U.S. banks' general reduction in claims on emerging-market counterparties contrasted with the rise in claims held by most European banks. Banks from European countries appear to be expanding cross-border lending to emerging-market counterparties, despite the events of recent years, whereas U.S. banks have focused their efforts more on Latin America. Japanese banks have had little choice but to scale back their emerging-market business because of capital pressures.

\section{U.S. COUNTRY EXPOSURE DATA BEFORE 1997}

Supervisors still draw on valuable lessons from the past in evaluating recent country exposure data. While it is not within the scope of this article to conduct an extensive analysis of country exposure data over several decades, a brief examination of trends since 1982 provides a necessary context for more accurate analysis of the 1997-99 period..$^{21}$ In particular, drawing comparisons with data from crises in the 1980s, in which U.S. banks suffered sizable losses on their developing-country portfolios, is useful. ${ }^{22}$

Despite some changes in how claims are reported, data from before and after 1997 are relatively comparable. $^{23}$ Therefore, it is possible to view the 1997-99 period in the context of broader trends in country exposure, including claims on emergingmarket counterparties.

\section{Cross-Border and Local Claims, 1982 to 1998}

In examining country exposure data for selected years from 1982 to 1998 , the first item of interest is that total claims on counterparties in emerging-market countries-in absolute terms - were nearly as high in the 1980s as in 1998, with cross-border claims in 1982 and 1986 actually exceeding cross-border claims in 1998 (table 12). However, local claims

21. Data from 1998 are included to provide an overlapping comparison (at intervals of four years) of earlier data with the 1997-99 period.

22. U.S. banks began reporting on the Country Exposure Report in 1978 , so the data series captures the entire period of crisis in developing countries during the 1980 s.

23. As discussed earlier, data on revaluation gains were not collected before June 1997. In addition, the definition of local claims was altered slightly in June 1997. However, cross-border measures are nearly identical before and after June 1997, and the definitional change in local claims affects only a few countries. (See note 3 in box "Types of Claims.") underwent tremendous growth from 1982 to 1998-an astounding 566 percent. The increasing importance of local claims during the 1997-99 period is thus part of a long-term trend. In some sense, this trend reflects the market penetration achieved by U.S. banks in local banking markets during the past decade. In addition, the relatively larger portion of local claims means that the transfer risk element of country risk is lessened insofar as more claims are denominated and funded in local currency. ${ }^{24}$ However, the counterparty credit risk element of country exposure may have increased because in the recent period, fewer claims have an explicit or implicit public-sector guarantee than in the period before 1997. ${ }^{25}$

\section{Distribution by Counterparty Sector, 1982 to 1998}

The composition, not just the levels, of emergingmarket claims changed from the 1980s to the late 1990 s, particularly the distribution of claims by counterparty sector. ${ }^{26}$ In 1986 and 1990, cross-border claims on the public sector represented one-half of total cross-border claims. Soon thereafter, the shift away from public-sector lending began; by 1998 the distribution had changed markedly, with claims on the nonbank private sector at nearly one-half of total claims. Although there was a general shift toward the nonbank private sector, claims on publicsector counterparties in Latin America and claims on banks in Asia remained significant.

\section{Distribution by Maturity, 1982 to 1998}

The maturity distribution has also shifted since the early 1980s, with more claims classified as shortterm (one year or less). In 1982, short-term claims represented one-half of all claims but fell below 50 percent in 1986 and 1990. By 1994, short-term claims had risen, to 60 percent of total claims. This

24. Transfer risk applies to cross-border claims and any local claims not funded by local liabilities. For the most part, growth in local liabilities has kept pace with growth in local claims.

25. The significance of this development became clear in both the Asian and the Russian crises, as expectations that local country governments would provide guarantees for banks and nonbank companies were not realized.

26. The same methodology used to examine data from the 1997-99 period fits this broader comparison as well, except that cross-border revaluation gains were not reported before 1997 and thus are excluded from the 1998 figures to ensure comparability. 
fluctuation in short-term claims as a percentage of total claims may have been directly tied to the developing-country debt crisis. Specifically, as emerging-market counterparties encountered difficulty in repaying debts, U.S. banks closed out many of their short positions and ceased to roll over short-

12. Claims of U.S. banks on foreign counterparties, by type of claim and region, selected years, 1982-98

\begin{tabular}{|c|c|c|c|c|c|}
\hline Item & 1982 & 1986 & 1990 & 1994 & 1998 \\
\hline & \multicolumn{5}{|c|}{ Total claims (millions of dollars) } \\
\hline Developed countries and banking centers $\ldots \ldots$ & 278,948 & 286,671 & 269,235 & 280,718 & 466,965 \\
\hline Cross-border $\ldots \ldots$. & $\begin{array}{r}213,478 \\
65,470\end{array}$ & $\begin{array}{l}185,713 \\
100958\end{array}$ & $\begin{array}{l}152,314 \\
116,921\end{array}$ & $\begin{array}{l}160,218 \\
120,500\end{array}$ & $\begin{array}{l}259,314 \\
207.651\end{array}$ \\
\hline Emerging markets & 150,925 & 132,988 & 85,281 & 122,724 & 176,129 \\
\hline Cross-border & 137,040 & 116,072 & 61,938 & 79,876 & 83,629 \\
\hline Local ............ & 13,885 & 16,916 & 23,343 & 42,848 & 92,500 \\
\hline Africa ... & 7,612 & 4,110 & 2,344 & 1,682 & 3,069 \\
\hline Cross-border & 7,119 & 3,662 & 1,898 & 1,131 & 1,213 \\
\hline Local ........ & 493 & 448 & 446 & 551 & 1,856 \\
\hline Asia-Pacific & 46,614 & 36,581 & 31,919 & 51,199 & 63,188 \\
\hline Cross-border & 40,558 & 28,190 & 18,204 & 27,237 & 23,386 \\
\hline Local ........ & 6,056 & 8,391 & 13,715 & 23,962 & 39,802 \\
\hline Eastern Europe & 5,876 & 3,710 & 2,086 & 4,551 & 7,916 \\
\hline Cross-border & 5,876 & 3,585 & 1,830 & 2,424 & 4,292 \\
\hline Local ........ & 0 & 125 & 256 & 2,127 & 3,624 \\
\hline Latin America & 90,823 & 88,587 & 48,932 & 65,292 & 101,956 \\
\hline Cross-border & 83,487 & 80,635 & 40,006 & 49,084 & 54,738 \\
\hline \multirow[t]{2}{*}{ 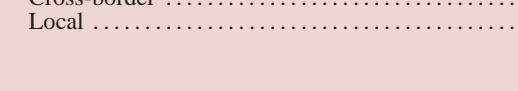 } & 7,336 & 7,952 & 8,926 & 16,208 & 47,218 \\
\hline & \multicolumn{5}{|c|}{ Total claims as a percentage of total assets } \\
\hline Developed countries and banking centers . & 22.1 & 17.8 & 14.4 & 12.8 & 11.5 \\
\hline Cross-border & 16.9 & 11.5 & 8.1 & 7.3 & 6.4 \\
\hline Local $\ldots . . . \ldots \ldots . . .$. & 5.2 & 6.3 & 6.2 & 5.5 & 5.1 \\
\hline Emerging markets & 12.0 & 8.2 & 4.5 & 5.6 & 4.3 \\
\hline Cross-border & 10.9 & 7.2 & 3.3 & 3.6 & 2.1 \\
\hline Local $\ldots \ldots \ldots \ldots \ldots \ldots \ldots$ & 1.1 & 1.0 & 1.2 & 2.0 & 2.3 \\
\hline Africa ......... & 6 & .3 & .1 & .1 & .1 \\
\hline Cross-border & .6 & .2 & .1 & .1 & .0 \\
\hline Local ........ & .0 & .0 & .0 & .0 & .0 \\
\hline Asia-Pacific ... & 3.7 & 2.3 & 1.7 & 2.3 & 1.6 \\
\hline Cross-border & 3.2 & 1.7 & 1.0 & 1.2 & .6 \\
\hline Local ........ & .5 & .5 & .7 & 1.1 & 1.0 \\
\hline Eastern Europe & .5 & .2 & .1 & .2 & .2 \\
\hline 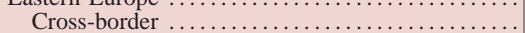 & .5 & .2 & .1 & .1 & .1 \\
\hline 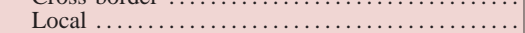 & .0 & .0 & .0 & .1 & .1 \\
\hline Latin America & 7.2 & 5.5 & 2.6 & 3.0 & 2.5 \\
\hline Cross-border & 6.6 & 5.0 & 2.1 & 2.2 & 1.4 \\
\hline \multirow[t]{2}{*}{ 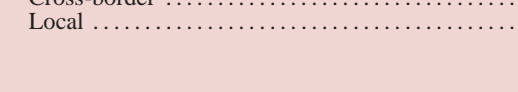 } & .6 & .5 & .5 & .7 & 1.2 \\
\hline & \multicolumn{5}{|c|}{ Total claims as a percentage of total capital } \\
\hline Developed countries and banking centers . & 395.1 & 246.7 & 166.5 & 125.3 & 110.2 \\
\hline Cross-border .. & 302.4 & 159.8 & 94.2 & 71.5 & 61.2 \\
\hline Local $\ldots . . . \ldots \ldots . . . .$. & 92.7 & 86.9 & 72.3 & 53.8 & 49.0 \\
\hline Emerging markets & 213.8 & 114.4 & 52.7 & 54.8 & 41.6 \\
\hline Cross-border & 194.1 & 99.9 & 38.3 & 35.7 & 19.7 \\
\hline Local ........ & 19.7 & 14.6 & 14.4 & 19.1 & 21.8 \\
\hline Africa $\ldots \ldots$ & 10.8 & 3.5 & 1.4 & .8 & $\begin{array}{r}21.0 \\
.7\end{array}$ \\
\hline Cross-border & 10.1 & 3.2 & 1.2 & .5 & .3 \\
\hline Local ........ & .7 & .4 & .3 & .2 & .4 \\
\hline Asia-Pacific & 66.0 & 31.5 & 19.7 & 22.9 & 14.9 \\
\hline Cross-border & 57.4 & 24.3 & 11.3 & 12.2 & 5.5 \\
\hline Local ........ & 8.6 & 7.2 & 8.5 & 10.7 & 9.4 \\
\hline Eastern Europe & 8.3 & 3.2 & 1.3 & 2.0 & 1.9 \\
\hline Cross-border & 8.3 & 3.1 & 1.1 & 1.1 & 1.0 \\
\hline Local ........ & .0 & .1 & .2 & .9 & .9 \\
\hline Latin America & 128.6 & 76.2 & 30.3 & 29.2 & 24.1 \\
\hline Cross-border & 118.3 & 69.4 & 24.7 & 21.9 & 12.9 \\
\hline Local ........ & 10.4 & $\begin{array}{r}0.4 \\
6.8\end{array}$ & $\begin{array}{r}24.1 \\
5.5\end{array}$ & 7.2 & 11.1 \\
\hline
\end{tabular}

NotE. In this table, figures for claims as a percentage of total assets and for claims as a percentage of total capital in 1998 are not consistent with 1998 figures in table 8 for two reasons: The figures in this table do not include

revaluation gains (see text note 26); also total capital is used in this table instead of tier 1 capital (see text note 28 ). 
term claims, leaving mostly longer-term claims. ${ }^{27}$ So the percentage of short-term claims in the total fell. U.S. banks later became more comfortable extending new credits to emerging markets, starting with short-term claims. The resumption of short-term lending was perhaps an indicator of U.S. banks' changed attitude toward lending to emerging-market counterparties.

\section{Claims Relative to Total Assets and Capital, 1982 to 1998}

More revealing comparisons emerge from an examination of claims as a percentage of total assets and claims as a percentage of capital. ${ }^{28}$ Claims on counterparties in emerging-market countries as a percentage of total assets were as high as 12 percent in 1982 but fell sharply, as banks reduced their emergingmarket portfolios during the debt crisis of the 1980s. Claims on emerging-market counterparties as a percentage of total capital in 1982 were well above 200 percent, much larger than the 42 percent recorded in 1998.

The fallout from the debt crisis of the 1980s caused the major downward shift in claims as a percentage of total assets and claims as a percentage of capital. By 1990, U.S. banks had lowered their claims-tocapital ratios, primarily as a result of the decrease in total claims as U.S. banks retrenched (chart 3). In 1994 and 1998, the reduction in the claims-to-capital percentages came as a result of improved capital positions and not from a reduction in claims.

In the 1980s, U.S. banks' emerging-market claimsto-capital ratios were much higher than current ratios. The overall decline in these ratios provides some assurance that emerging-market country exposure poses less of a potential threat to U.S. banks today than a decade ago. However, the relative riskiness of claims must be taken into account to develop a more accurate overall picture of those risks. Also, there is an increasing trend toward marking claims to market, meaning that a change in their value can have a direct effect on a bank's reported income; in the 1980s, the process of first provisioning for, and then writing off, claims meant that losses in emerging markets were

27. The short-term claims that were granted anew often came in the form of trade credits, which were considered much less risky.

28. Because tier 1 capital was not reported before 1990, capital figures used in the comparisons consist of equity capital, subordinated debentures, and reserves for loan losses, or what is referred to as total capital. This measure of capital was used on the Country Exposure Lending Survey until 1998, when tier 1 capital was adopted.
3. U.S. banks' emerging-market claims compared with total capital, selected years, 1982-98

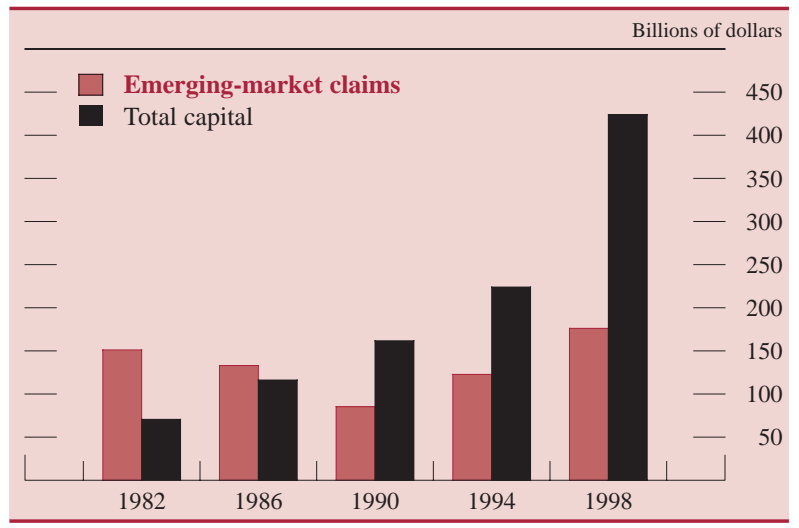

NoTE. Data for 1998 were included to provide an overlapping comparison (at intervals of four years) of earlier data with the data from 1997-99. However, data on revaluation gains were not collected before 1997, so revaluation gains for 1998 were excluded from this chart to ensure comparability with data from earlier years. Total capital data cover only banks that file the Country Exposure Report.

Because tier 1 capital was not reported before 1990, capital figures used in these comparisons consist of equity capital, subordinated debentures, and reserves for loan losses, or what is referred to as total capital. This measure of capital was used in the Country Exposure Lending Survey until 1998, when tier 1 capital was adopted.

reported on a lagged basis. While the trend toward better disclosure is generally welcome, it does mean that any losses may have an immediate, and sometimes volatile, effect on banks' capital, forcing them to be more adept at managing risks in relation to their capital. Indeed, U.S. banks today apply a number of risk-management techniques that were not widely used in the 1980s, such as measurements of potential exposure, distributions of possible loss amounts, and estimates of capital at risk.

\section{CONCLUSION}

U.S. banks continue to be active in emerging-market countries despite the crises in recent years. Claims held by U.S. banks on counterparties in Asia and Eastern Europe declined over 1997-99, as U.S. banks either suffered losses on claims or actively reduced their exposure to those regions. Claims on counterparties in Latin America increased over the period, perhaps an indication that U.S. banks rely on their longer-standing, more entrenched ties to that region and likely view it as a strategic growth area. However, for all regions the claims-to-capital ratios have fallen, a result of U.S. banks bolstering their capital over the entire period-international crises notwithstanding.

Banking supervisors determine the potential threat from international exposures by identifying risk areas 
among foreign claims, assessing the capital supporting those claims, and evaluating banks' ability to manage the risks associated with those claims. In particular, high claims-to-capital ratios for U.S. banks act as a signal for supervisors to focus on specific U.S. banks or, in some cases, groups of banks. Such a signal, in turn, may require a more detailed analysis of country risk at the institutions in question. Finally, supervisors evaluate the manner in which country risk is being managed along with the other risks facing U.S. banks. 